\title{
Corporate Governance and Social Responsibility: The Case of Nepal
}

\section{Suman Acharya, PhD}

\section{Email: sumanacharaya@gmail.com}

\begin{abstract}
No company operates in vacuum rather it operates in the society. The structure of corporate governance is framed under the prescription of laws and regulation of the country. It consists of Board of Directors, Management Committee, Audit Committee, various Committees and Sub-Committees prescribed under the provision of legal system. It makes effort to realize its objectives through good governance, control system and transparency etc. It avoids any form of conflict of interest between ownership and control. Moreover, corporate social responsibility is the one important dimensions of corporate governance, which serves for the benefit of internal stakeholders, external stakeholders and the society as whole. Only the maximization of profit is not a goal of the incorporated body rather it has to support various sector as per their capacity and financial resources of the incorporated body. Conversely, corporate social responsibility shouldn't be guided by vested interest of misappropriation of the fund. And, COVID-19 scenario has invoked incorporated body to realize their social responsibilities from new horizon further.
\end{abstract}

Key Words: corporate governance, corporate social responsibility, OECD, Basel committee, control system, international instruments.

\section{Introduction}

Corporate governance, an overall management of incorporated body, operates the institution under national and international standards. It is expected to perform each and every organic structure well. It should be responsible towards internal stakeholders, 
external stakeholders and society as a whole. The establishment of organization possesses its own functioning under corporate governance and it has an obligation to strengthen internal, external and general environment. Now that institution performs strongly but other social system operates poorly that exhibits adversity and paradoxical; so, institution requires to be responsible to internal and external stakeholders along with the effective governance of the organization. Altogether, it is the issue of enhancing human development based on the strength and capacity of the organization. Corporate governance is a 'set of internal and external control mechanisms that reduce the conflicts of interest between managers and shareholders deriving from the separation of ownership and control. ${ }^{1}$ (Berle and Means, 1932; Fama and Jensen, 1983; Shleifer and Vishny, 1986) They are expected to perform accordingly with the provision of existing laws and regulations. Even in external relation of the organization, it may be cost effective issues and specialization of the task by employing them. Yet, conflict of interest is rejected as any cost in the operation of the organization. So, regulators, Annual General Meeting, Special General Meeting, Board, Management Committee, Audit Committee, Risk Management Committee, Auditors, Shareholders, and staffs are involved in corporate governance process so that malfunction may not be occurred. ${ }^{2}$

\section{OECD Principles}

According to Organization of Economic Cooperation and Development (OECD, 2015), the principles of corporate governance are 'ensuring the basis for an effective corporate governance framework, the rights and equitable treatment of shareholders and key ownership functions, institutional investors, stock markets, and other intermediaries, the role of stakeholders in corporate governance, disclosure and transparency, the

$1 \quad$ Cited in Federico Munari and Maurizio Sobrero. (2003). Corporate Governance and Innovation, in Mario Calderini, Paola Garrone, Maurizio Sobrero (Ed.). Corporate Governance, Market Structure and Innovation. 3 (2003). Edward Elgar: Cheltenham, UK. .

2 Vide Gordon L. Clark and Dariusz Wójcik. Geography of Finance; Corporate Governance in the Global Market Place. 31-56. (2007). Oxford University Press. 
responsibilities of the board'. ${ }^{3}$ It recommends corporate body of the world to operate efficiently and effectively. Additionally, the World Bank and the OECD makes two major initiatives which are an OECD Global Corporate Governance Forum (GCGF) and a series of Regional Policy Dialogue Round Tables in order to assist individual project and to make recommendation on the improvement of corporate governance. (OECD, 2001) It works as a forum of policy dialogue with various stakeholders. ${ }^{4}$

The regulator of incorporated body has been established in each country of the world. Their responsibility is to establish and maintain corporate governance in the jurisdiction. As auditing is the part of checking financial health of the organization, ${ }^{5}$ Nepal implements Nepal Financial Reporting Standards (NFRS) in auditing process. Anything which has not been covered in these documents, the International Financial Reporting Standards (IFRS) will be applicable. Together, it implements the recommendations of the IMF, the World Bank Group and other regional organizations if so are applicable. OECD recommends for qualified and concerned person to the organization, strategic objectives and corporate values, clear lines of responsibility, oversight of senior management, internal and external audit, internal control system, good corporate cultures, transparency, knowledge of own structures etc. The ultimate responsibilities of banks and financial institutions go the Board of Directors.

3 Vide OECD. G20/OECD Principles of Corporate Governance. (2015). OECD Publishing, Paris. https://doi.org/10.1787/9789264236882-en. OECD Ministers adopted the OECD Principles in June 1999. There was the participation of 29 OECD Member governments and the European Commission, private parties, the World Bank, IMF, and other international organisations.

4 Vide OECD. International Efforts to Improve Corporate Governance: Why and How. (2001) http://www.oecd.org/corporate/ca/corporategovernanceprinciples/1932028.pdf.

5 Vide Denis, D., \& McConnell, J.. International Corporate Governance. The Journal of Financial and Quantitative Analysis. 1-36. (2003). 38(1). doi:10.2307/4126762. 


\section{Basel Committee}

Core Principles for Effective Banking Supervision (2011) mentions corporate governance in principle number fourteen ${ }^{6}$ and risk management process in principle number fifteen. ${ }^{7}$ Bank for International Settlement (2015) highlights Corporate Governance Principle for Banks as below table. ${ }^{8}$ In fact, corporate governance includes all aspect of the organization to perform under the standards and functional aspect of it.

\section{Corporate Governance Principle}

- Principle 1: Board's overall responsibilities

- Principle 2: Board qualifications and composition

- Principle 3: Board's own structure and practices

- Principle 4: Senior management

- Principle 5: Governance of group structures (Parent and subsidiary)

- Principle 6: Risk management function

- Principle 7: Risk identification, monitoring and controlling

- Principle 8: Risk communication

- Principle 9: Compliance

(Source: BIS, 2015)

Principle 14: Corporate governance, Core Principles for Effective Banking Supervision, 201. It reads as 'Principle 14: 'The supervisor determines that banks and banking groups have robust corporate governance policies and processes covering, for example, strategic direction, group and organisational structure, control environment, responsibilities of the banks' Boards and senior management, and compensation. These policies and processes are commensurate with the risk profile and systemic importance of the bank.' Vide Core Principles for Effective Banking Supervision. https://www.bis.org/publ/bcbs213.pdf, ( Last Visited on 5/17/2020).

$7 \quad$ Principle 15, Ibid. It reads as 'Principle 15: Risk management process: The supervisor determines that banks have a comprehensive risk management process (including effective Board and senior management oversight) to identify, measure, evaluate, monitor, report and control or mitigate all material risks on a timely basis and to assess the adequacy of their capital and liquidity in relation to their risk profile and market and macroeconomic conditions. This extends to development and review of robust and credible recovery plans, which take into account the specific circumstances of the bank.' Vide Core Principles for Effective Banking Supervision. https://www.bis.org/publ/bcbs213.pdf, (Last visited on 5/17/2020).

8 Corporate governance Principle for Banks, 2015- Bank for International Settlement. https://www.bis.org/bcbs/publ/d328.pdf (Last Visited on 5/17/2020). 


\section{Principles of Corporate Responsibility}

The principle of profit maximization has lost its sanctity unless it serves society and relevant stakeholders. Respect to human rights, priority to local people in opportunity, adaptation of labour standard, consumer protection etc are the additional obligation of the organization either under legal standard or in free choice social responsibility notions. Many regard social responsibility as a part of distributive justice. It links organization to civil society and the government. Corporate social responsibility grants organizational benefit for the sake of minority shareholder, employee, government, society, customers etc. It pursues both moral and legal obligations. Sustainable development and social welfare are the basic dimensions of corporate social responsibility.

- Corporate Citizenship: It encourages organization to perform not only core business activities but also social activities. Part of the company requires investing in society for the common benefit.

- Distribution of Profit: This concept has changed traditional concept of doing business so far because organization shouldn't only focus on business profit but also distribution of it to society in the form of social welfare. Constitutional stakeholders have primary rights over it.

- Environmental Responsibility: After following millennium development goals, United Nations adopted sustainable development goals for world community. It is expected to implement not only by the government but also by the incorporated body of the society. Large portion of it goes to private sectors.

- Human Rights: It is the peremptory norms of contemporary society. No organization can breach human rights and their fundamental freedom. It aims to maximize the humanity to the larger extent with greatest positive measures.

- Minority Protection: There are various stakeholders in which organization requires to make protection if they are dominant in decision making process. Each organic body and their components are required to protect. 
- Rectification of Harm: Organization should be ready to rectify in case any harm has been taken place with the activities in society. It is not only in social compensation but also internal compensation.

- Rule of Law: As rule of law is the part of natural justice, every organization is to be expected and performed under law. It should follow justice, equality, equity, good conscience etc.

- Social Audit: It refers to make participation of consumer and employee from socialization institutions like Trade Union, Independent Director, and Shareholder etc. It equally needs social dialogue in policy matter so that minimum standard of the organization cannot be crossed out. Many countries have appointed ombudsman for this purpose.

- Social Obligations: It is expected that all the components of society have been developed equally. Organization with profitability can launch the program to boost marginalized people and society and their involvement in social activities. Yet, it cannot violate national integrity, sovereignty and public morals.

\section{International Instruments on Corporate Responsibility}

Because of the globalization, the trend of establishment of transnational business has been increasing and ever increasing than ever before in unprecedented way. That is why; it forces to make the guideline applicable universally. Some of them carry as follow.

- OECD Guidelines for Multinational Enterprises, 2000: It recommends multinational enterprises to operate in harmony with the policy of the local governments. Responsible business conducts are the motto of it. ${ }^{9}$

- The ILO Tripartite Declaration of Principles Concerning Multinational Enterprises and social policy, 1997: These principles are laid down for the government, employee association, employer association, multinational enterprises and related stakeholders on the issue of job security, work place safety,

9

OECD.

OECD

Guideline

for

Multinationa

Enterprises.

(2011) https://www.oecd.org/corporate/mne/1922428.pdf. (Last Visited on 5/13/2020). 
industrial relations etc. ${ }^{10}$ It incorporates international labour conventions and recommendations issues.

- The UN Global Compact, 2000: It recommends stakeholders to comply fundamental principles of human rights, labour, environment, anti corruptions etc. ${ }^{11}$

- ILO Declaration on Fundamental Principles and Rights at Work, 1998: It recommends both member and nonmember to respect freedom of association, collective bargaining, elimination of forced labour, rejection of child labour, elimination of the discrimination of any form. ${ }^{12}$

- The Global Sullivan Principles, 1999: It supports for economic, political and social justice in the time of doing business activities. Greater level of understanding of people has been expected by these principles. ${ }^{13}$

Vide International Labour Organisation, 2017, Tripartite Declaration of Principles concerning Multinational Enterprises and Social Policy. https://www.ilo.org/wcmsp5/groups/public/---ed_emp/--emp_ent/---multi/documents/publication/wcms_094386.pdf. (Last Visited on 5/13/2020). The Ten Principles of the United Nations Global Compact are derived from: the Universal Declaration of Human Rights, the International Labour Organization's Declaration on Fundamental Principles and Rights at Work, the Rio Declaration on Environment and Development, and the United Nations Convention Against Corruption. Principles are; Human Rights: Principle 1: Businesses should support and respect the protection of internationally proclaimed human rights; and Principle 2: make sure that they are not complicit in human rights abuses. Labour: Principle 3: Businesses should uphold the freedom of association and the effective recognition of the right to collective bargaining; Principle 4: the elimination of all forms of forced and compulsory labour; Principle 5: the effective abolition of child labour; and Principle 6: the elimination of discrimination in respect of employment and occupation. Environment: Principle 7: Businesses should support a precautionary approach to environmental challenges; Principle 8: undertake initiatives to promote greater environmental responsibility; and Principle 9: encourage the development and diffusion of environmentally friendly technologies. Anti-Corruption: Principle 10: Businesses should work against corruption in all its forms, including extortion and bribery. For details, vide Ten Principles of the UN Global Compact. https://www.unglobalcompact.org/what-is-gc/mission/principles. (Last Visited on $5 / 13 / 2020)$.

ILO Declaration on Fundamental Principles and Rights at Work and its Follow-up. https://www.ilo.org/declaration/thedeclaration/textdeclaration/lang--en/index.htm. (Last Visited on 5/13/2020). $5 / 13 / 2020)$. 
- The Caux round Table Principles for business, 1994: Its focus goes on economic and social justice with respect to human dignity. Realization of cooperation, mutual prosperity and common goods for all is the target of it. ${ }^{14}$

- Amnesty International Guidelines for Companies, 1998: Amnesty International has issued human rights principles for the company. Business community has both moral and legal obligation to the stakeholders. ${ }^{15}$ It endorses responsibility of own operation and security of it.

- Social Accountability Standard, 1998 (SA8000): It emphasizes on decent work and implementation of international human rights instruments and labour rights instruments. ${ }^{16}$

- The ICC's Nine Steps to Responsible Business Conduct, 2002: Responsible business conduct of the organization, link between purpose and values of the company, identification of key stakeholders, definite business principles and policies, implementation procedure and management system, own benchmark, internal monitoring, understandable language, pragmatic and realistic objectives are the principles of responsible business. ${ }^{17}$

- Global Reporting Initiative Guidelines, 2002: It recommends transparency, inclusiveness, auditability, completeness, relevance, sustainability context, accuracy, neutrality, comparability, clarity, timeliness as principles of sustainable reporting. ${ }^{18}$ It covers all the process of reporting.

14 15 on $5 / 13 / 2020)$.

Caux Round Table: Principles for Business, http://hrlibrary.umn.edu/instree/cauxrndtbl.htm. (Last Visited

Amnesty International. Human Rights Principles For Companies. (1998) https://www.amnesty.org/download/Documents/148000/act700011998en.pdf (Last Visited on 5/13/2020).

$\begin{array}{llllll}\text { Social Accountability Standard. SOCIAL ACCOUNTABILITY } 8000 . & \text { (2001). }\end{array}$ http://www.sa8000.info/sa8000doc/2001StdEnglish.pdf (Last Visited on 5/13/2020).

The International Chamber of Commerce, the World Business Organization. Business in society Making a positive and responsible contribution A voluntary commitment by business to manage its activities responsibly. (2002). https://iccwbo.org/content/uploads/sites/3/2004/06/Nine-practical-steps-to-responsiblebusiness.pdf. (Last Visited on 5/13/2020).

Global Reporting Initiatives. Sustainability Reporting Guideline. (2002). https://www.aeca.es/old/comisiones/rsc/documentos_fundamentales_rsc/gri/guidelines/gri_guidelines_200 2.pdf. (Last Visited on 5/13/2020). 


\section{- CSR; Corporate Social Responsibility and the Role of the Legal Profession: A}

Guide for European Lawyers Advising on Corporate Social Responsibility Issue, 2003: As lawyer has indispensable role in corporate law implementation, it can make advice for their clients to work for corporate social responsibilities. It deals with corporate social responsibility initiatives in the delineation of European countries. ${ }^{19}$

- UN Norms on Responsibilities of Transnational Corporations and other Business Enterprises with regard to Human Rights, 2003: It recommends transnational corporation for equal opportunity, nondiscriminatory treatment, and security of persons, respect of national sovereignty and other human rights obligations. $^{20}$

\section{Discussion}

Based on the response of open ended qualitative questionnaire of 50 respondents, they favor certain threshold of profit to be spent for internal and external stakeholders including society. It is expected to make mandatory in case of the profit has been generated by the organization. The area of corporate social responsibility depends on the necessity of people and society. Company shouldn't only focus on mandates; they should voluntarily launch the corporate social responsibility related activities.

\begin{tabular}{|l|l|l|}
\hline SN & Issues & Response \\
\hline 1. & $\begin{array}{l}\text { Expenditure of profit for capacity } \\
\text { building program }\end{array}$ & $\begin{array}{l}\text { Some of the respondents argue for the } \\
\text { sufficient capacity building program } \\
\text { within organization i.e. training for }\end{array}$ \\
\hline
\end{tabular}

19 CCBE . CSR; Corporate Social Responsibility and the Role of the Legal Profession: A Guide for European Lawyers Advising on Corporate Social Responsibility Issue. (Sept. 2003). https://www.ccbe.eu/fileadmin/speciality_distribution/public/documents/CSR/CSR_Guides recommend ations/EN_CSR_20030930_CSR-and-the-role-of-the-legal-profession-a-guide-for-European-lawyersadvising-on-corporate-social-responsibility-issues.pdf. (Last Visited on 5/13/2020).

20 Norms on the Responsibilities of Transnational Corporations and Other Business Enterprises with Regard to Human Rights. U.N. Doc. E/CN.4/Sub.2/2003/12/Rev.2. (2003). http://hrlibrary.umn.edu/links/normsAug2003.html. (Lat Visited on 5/13/2020). 


\begin{tabular}{|l|l|l|}
\hline 2. & Public awareness in ongoing issues & $\begin{array}{l}\text { directors, promoters, shareholders, } \\
\text { employee and customers. }\end{array}$ \\
\hline 3. & Social welfare activities & $\begin{array}{l}\text { Organization in profit has to launch the } \\
\text { awareness program of contemporary } \\
\text { issues i.e. COVID-19, earthquake, any } \\
\text { other natural disaster and calamities. }\end{array}$ \\
\hline 4. & Free service during calamities & $\begin{array}{l}\text { It concerns for the organizational effort to } \\
\text { make support in sanitation, public drinking } \\
\text { water facilities, construction of rest room } \\
\text { and siesta places, launch of free health } \\
\text { camp etc based on organizational policy. }\end{array}$ \\
\hline 6. & Literacy program & $\begin{array}{l}\text { Organization can provide free service } \\
\text { wholly or partially during calamities to the } \\
\text { clients so that public can get benefit, } \\
\text { which makes public opinion positive to the } \\
\text { organization. }\end{array}$ \\
\hline 5. & $\begin{array}{l}\text { Conservation and protection of } \\
\text { cultural heritage }\end{array}$ & $\begin{array}{l}\text { The renovation of archeologically and } \\
\text { culturally important site and sanitation of } \\
\text { public places and cultural places can be } \\
\text { important activities for corporate social } \\
\text { responsibility in Nepal. }\end{array}$ \\
\hline $\begin{array}{l}\text { In contemporary issues, organization can } \\
\text { launch literacy program in needy area so } \\
\text { that the life style of downtrodden people } \\
\text { can be improved. It can be financial } \\
\text { literacy, technological literacy, health } \\
\text { literacy, agricultural literacy etc. }\end{array}$ \\
\begin{tabular}{l} 
If the economic resources are not \\
\hline
\end{tabular}
\end{tabular}




\begin{tabular}{|l|l|l|}
\hline 8. & Scholarship program & $\begin{array}{l}\text { sufficient, a kind of game to generate } \\
\text { funds for public work through sponsorship } \\
\text { can be established. }\end{array}$ \\
\hline 9. & $\begin{array}{l}\text { Funding for community school, } \\
\text { college and hospital }\end{array}$ & $\begin{array}{l}\text { needy people and geography based on } \\
\text { their economic conditions and merits. It } \\
\text { can strengthen the capacity of the society } \\
\text { in a long term. }\end{array}$ \\
\hline 10. & $\begin{array}{l}\text { If the infrastructure of the community } \\
\text { school, college and hospital is poorly } \\
\text { maintained, company can extend their } \\
\text { developmental activities }\end{array}$ & $\begin{array}{l}\text { As there is the necessity of large fund in } \\
\text { infrastructure development of the state, } \\
\text { company with profit can contribute certain } \\
\text { amount of money in such developmental } \\
\text { activities if so is of public utilities. } \\
\text { Ultimately, company themselves are the } \\
\text { beneficiary of it. }\end{array}$ \\
\hline & Source: Qualitative Questionnaire Survey, 2020 \\
\hline
\end{tabular}

\section{Legal Implications in Reference to Nepal}

Nepal has Company Act, 2063 BS (2006 AD), Banks and Financial Institutions Act, 2073 BS (2017 AD), Securities Act, 2063 BS (2007 AD), Competition Promotion and Market Protection Act, 2063 (2007), Environment Protection Act, 2076 BS (2019 AD), Income Tax Act, 2058 BS (2002 AD), Consumer Protection Act, 2075 BS (2018 AD), Industrial Enterprises Act, 2076 BS (2020 AD), Labour Act, 2074 BS (2017 AD), Children Act, 2075 BS (2018 AD) etc. These legislations establish special provisions for the protection 
and conservation of respective areas. If there are no provisions on special law, the provision of Company Act, 2063 BS (2006 AD) is applicable. It has both matter in corporate governance and corporate social responsibilities. Unified Directives Issued for Banks and Financial Institutions (Cass A, B and C) has established mandatory provision for these banks and financial institutions to establish Social Responsibility Fund with at least 1 percent of their net profit annually and shall expense on social project i.e. education, health, environment protection etc; direct subsidy expenditure to uplift poorly marginal sector of the society; sustainable development goals; child day care center, shelter for old age people etc. As Nepal has 7 provinces banks and financial institutions should proportionally make expense of social responsibility fund in diverse geography. At least 10 percent of it shall be expensed in every province of Nepal. ${ }^{21}$ The Companies Act, 2063 (2006 AD) has provided that no company contrary to prevailing laws, public interest, morality, decency, etiquette can be established. ${ }^{22}$ It prohibits granting donation or gift made for the welfare of its employees or for the promotion of its business no more than the 1 percent of the net profit of the last three year or one hundred thousand. ${ }^{23}$ Moreover, there is the provision of Non Distribution Profit Company which emphasizes the company for social responsibilities. ${ }^{24}$ The establishment of the Investor Protection Fund in company is also important issue on it. ${ }^{25}$

Even company Act prescribes to provide the information of vested interest of the director, ${ }^{26}$ information of the company having affiliations of close family members, ${ }^{27}$ restriction on sale of company or donation or transfer, ${ }^{28}$ preparation of the report and

\footnotetext{
21 No. 16, Good Governance Directives, Directives No. 6, Unified Directives Issued for Class A, Class B and Class C banks and Financial Institutions. 250. (2076), available at https://www.nrb.org.np/contents/uploads/2019/12/Directives-Unified_Directives_2076-new-1.pdf. (Last Visited on 5/14/2020).

The Companies Act, § sec. 6(1)(b) (2063).

Id. § sec.105 (1) (c).

Id. $\S$ sec.166 \& 167.

Id. § sec.183.

Id. $\S$ sec.92.

Id. § sec.93.

Id. § sec. 105 .
} 
financial statements, ${ }^{29}$ rejection of personal benefit, ${ }^{30}$ transaction and jurisdiction of the company, ${ }^{31}$ fine and imprisonment for false information, ${ }^{32}$

\section{Corporate governance of banks and financial institutions in Nepal}

\begin{tabular}{|c|c|c|}
\hline S.N. & Issues & Results \\
\hline 1. & Board Member & $\begin{array}{l}\text { Law mandates to make the board with } 5 \text { to } 7 \\
\text { members in the banks and financial institutions. }{ }^{33} \\
\text { They have certain academic qualifications and } \\
\text { experience in the field of business sectors. }{ }^{34} \\
\text { General Meeting appoints Board members, once } \\
\text { it has been taken place. Non compliance of } \\
\text { qualification hinders director to be appointed. }{ }^{35} \\
\text { The allowance and facilities of the board shall be } \\
\text { as prescribed. }{ }^{36} \text { Directors should take all the } \\
\text { responsibility of the operation of banks and } \\
\text { financial institutions. }{ }^{37} \text { They shouldn't take } \\
\text { personal benefit from the institutions. }{ }^{38} \text { They } \\
\text { should provide their profile information to the } \\
\text { banks and financial institutions once they are } \\
\text { appointed. }{ }^{39} \text { They are entitled to present the } \\
\text { information having conflict of interest if so. }\end{array}$ \\
\hline
\end{tabular}

Id. § sec.109.

Id. § sec.99.

Id. §sec.103.

Id. §sec.160 (A).

Banks and Financial Institutions Act § sec.14 (2073).

Id. § sec.16.

Id. § sec.18.

Id. § sec. 28 .

Id. $\S s e c .22$.

Id.§ sec. 23 .

Id. $\S$ sec. 24 .

Id.§ sec. 25 . 


\begin{tabular}{|c|c|c|}
\hline & & $\begin{array}{l}\text { Director cannot receive credit and facilities } \\
\text { having interest and influence to the institutions. }\end{array}$ \\
\hline 2. & $\begin{array}{l}\text { CEO appointment and } \\
\text { qualification }\end{array}$ & $\begin{array}{l}\text { Board of Directors appoints Chief Executive } \\
\text { Officer (CEO) based on internal and external } \\
\text { rules and legislations. }{ }^{41} \text { A person having Masters } \\
\text { Degree at least or the person having bachelors } \\
\text { degree with minimum prescribed experiences can } \\
\text { be appointed for this post. It works on behalf of } \\
\text { Board of Directors. }{ }^{42} \text { Board can delegate its } \\
\text { power to the CEO and other staffs. }{ }^{43}\end{array}$ \\
\hline 3. & Independent Director & $\begin{array}{l}\text { A person possessing more than } 0.1 \text { percent share } \\
\text { of the bank and financial institution is not eligible } \\
\text { to be independent director. }{ }^{44} \text { Masters degree in } \\
\text { business subject is necessary to become } \\
\text { independent director in commercial and } \\
\text { development bank. For regional development } \\
\text { bank and finance companies, academic } \\
\text { qualification is at least bachelor's degree. For } \\
\text { micro finance companies, it is as prescribed by } \\
\text { the central bank. }\end{array}$ \\
\hline 4. & Terms of office & $\begin{array}{l}\text { Board of Directors is appointed for four years } \\
\text { maximum of two consecutive terms of office. } \\
\text { Additionally, CEO is appointed for four years }\end{array}$ \\
\hline
\end{tabular}

Id.§ sec.29.

Id.§ sec.30.

Id.§ sec. 27 .

Id.§sec.14 (3).

Id. § sec.17.

Id . § sec.15. 


\begin{tabular}{|c|c|c|}
\hline & & $\begin{array}{l}\text { term and can be reappointed for another one } \\
\text { term. }{ }^{47} \text { Committee and subcommittee can be } \\
\text { established as per necessity. }{ }^{48} \text { Generally, Audit } \\
\text { Committee, Risk Management Committee, Staff } \\
\text { Service and Facilities Committee and AML/CFT } \\
\text { Committee can be established. }\end{array}$ \\
\hline 5. & Constitutional person & $\begin{array}{l}\text { No incumbent holding constitutional positions is } \\
\text { eligible in the Board of Directors or as the Chief } \\
\text { Executive of any bank or financial institution. }{ }^{49}\end{array}$ \\
\hline 6. & Inspection and supervision & $\begin{array}{l}\text { Nepal Rastra Bank as a regulator makes } \\
\text { inspection and supervision of banks and financial } \\
\text { institutions under Nepal Rastrra Bank Act, Banks } \\
\text { and Financial Institutions Act, Supervision } \\
\text { Byelaws etc. }\end{array}$ \\
\hline 7. & $\begin{array}{l}\text { Compliance to laws and } \\
\text { regulations }\end{array}$ & $\begin{array}{l}\text { Banks and financial institutions have to make } \\
\text { compliance with the order, circular and } \text { directives }^{50} \text { along with prevailing laws and } \\
\text { regulations. }\end{array}$ \\
\hline 8. & $\begin{array}{l}\text { Auditing; Internal and } \\
\text { External }\end{array}$ & $\begin{array}{l}\text { It has been mandated both by Companies Act and } \\
\text { Banks and Financial Institutions Act. It depicts } \\
\text { the financial health of the company and is the } \\
\text { benchmark of the corporate governance so that } \\
\text { weakness of the organization can be improved. }\end{array}$ \\
\hline 9. & Penalty & $\begin{array}{l}\text { It has two kinds of penalty; one to banks and } \\
\text { financial institutions and another to person }\end{array}$ \\
\hline
\end{tabular}

Id . § sec.29.

Id §sec.26.

Banks and Financial Institutions Act $\S$ sec.20 (2073).

Nepal Rastra Bank Act $\S$ sec.79 (2058). 


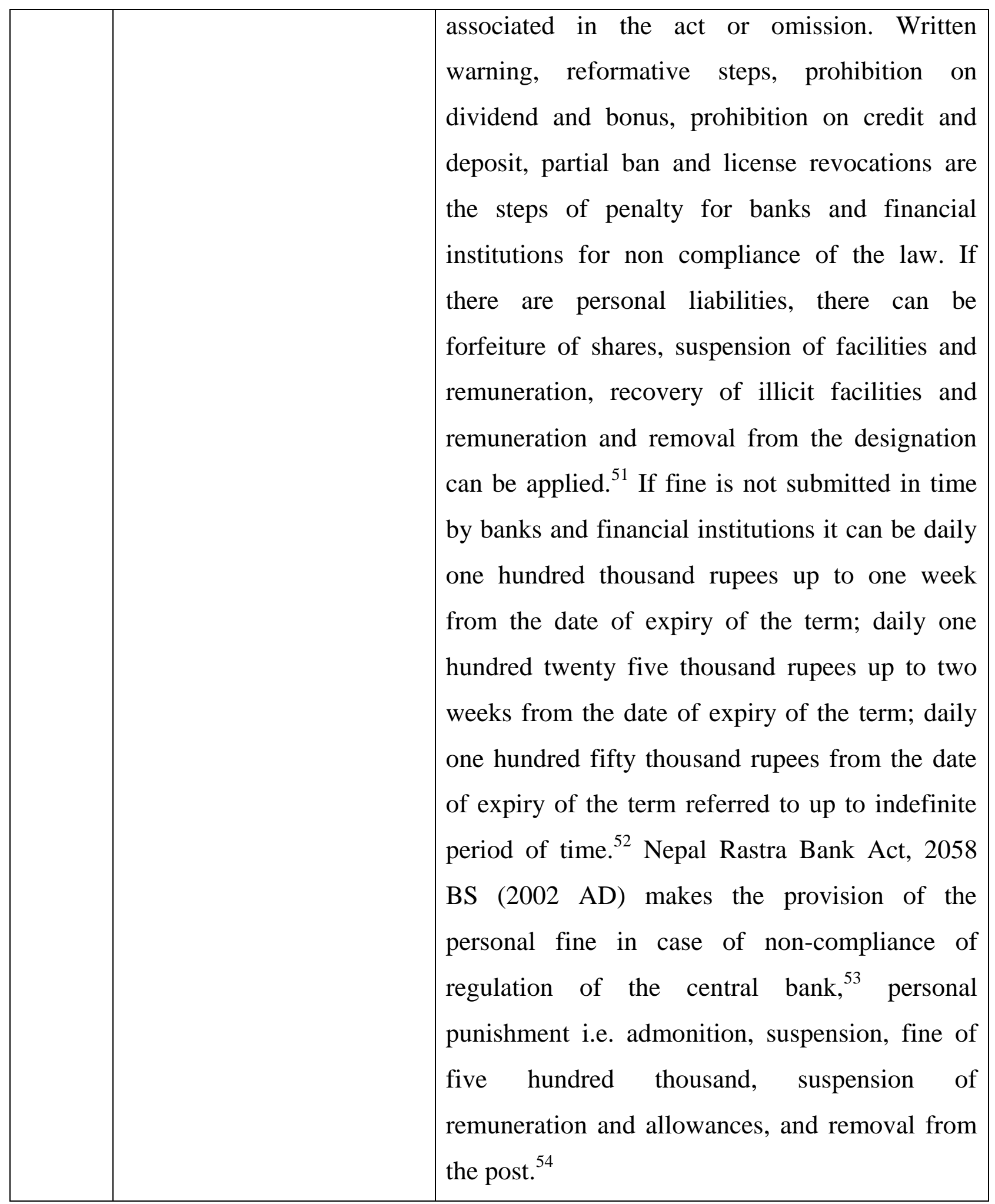

Id. § sec.99.

Id. § sec.100.

Nepal Rastra Bank Act, § sec.99(2) (2058).

Id. § sec.100(2). 


\section{Case laws}

- Surya Prasad Sharma Dhungel vs. Godabari Marble Industries Pvt. Ltd.: Respecting the social obligation of the company, Supreme Court of Nepal issued directive order to make relevant laws for the protection of environment and cultural heritage for the sake of mankind. It shows the responsibility of the organization towards the society. ${ }^{55}$

- Nepal Rastra Bank vs. Rajendra Kumar Khetan: The shareholder of the company cannot file the litigation on behalf of the company taking it's a personal property. Yet, it can file the case concerning their individual interest. It means they cannot be the representative of the company. Public body operating under instrumentality of the state has to disclose the information other than confidential matter. $^{56}$

- Nepal Rastra Bank vs. Arun Chand: Privilege and advantages without legal guarantee cannot be protected. It will be discretionary in nature. It was the issue of bank credit claimed as a privilege and advantage which cannot be possible. Boards of directors are responsible for the action of the company. ${ }^{57}$

\section{Conclusion}

As corporate governance is the part of national and international standards, corporate social activities are performed both in voluntarily and mandatorily. Incorporated body shouldn't only focus on profit but also serve benefit to stakeholder and social activities based on the capacity of the incorporated body. Also, as the incorporated bodies have huge resources, they are entitled to spend some of the portion of their benefit to the local society. So as the part of global and universal village concept, the standards of human

55 Golden Jublee Issue (2052) 1 D. no. 04. http://nkp.gov.np/full_detail/8883/?keywords=. (Last Visited on $5 / 12 / 2020)$.

56 N.K.P. 3 (2065) D. no. 7949. http://nkp.gov.np/full_detail/2285/?keywords=. (Last Visited on 5/12/2020). N.K.P. 11(2063) D. no. 7785, available at http://nkp.gov.np/full detail/2572/?keywords=. (Last Visited on $5 / 12 / 2020$.) 
rights and fundamental freedom accepted by benchmark setter organization cannot be forgotten. Rule of law, equity, respect to adjacent values, and service to local people are the benchmark of corporate social responsibility. In the context of Nepalese banking sector, there are cases having allegation of loan to personal vested interest i.e. relatives and company, turning deaf ear to good governance and policy documents, unnecessary meddling to the management, granting little time to the organization etc. Ultimately, the purpose of corporate governance is to establish good governance in the organization. The strategic guideline and policy has been formulated by the Board of Directors and are implemented by the Management Committee under national and internal standards and instruments with the support of various committees and employees.

\section{'The end...'}




\section{Annex One: Open Ended Questionnaires}

1. How do you link corporate governance with corporate social responsibility?

2. What is the condition of corporate responsibility if it fails to make minimum threshold of profit?

3. What types of activities of the company can be beneficial to stakeholders and the society?

4. How do you think corporate social responsibility as a mandatory or voluntary matter?

5. How is the condition of corporate responsibility in Nepal?

6. Has corporate social responsibility really been founded under its objectives in functional level? 